\title{
THE MEASUREMENT OF EXCHANGEABLE POTASSIUM IN MAN BY ISOTOPE DILUTION ${ }^{2}$
}

\author{
By LESLIE CORSA, JR.,2 JOHN M. OLNEY, JR., ${ }^{3}$ RICHARD W. STEENBURG, \\ MARGARET R. BALL, AND FRANCIS D. MOORE 4
}

\begin{abstract}
(From the Surgical Research Laboratories of the Peter Bent Brigham Hospital and the Department of Surgery of the Harvard Medical School, Boston)
\end{abstract}

(Submitted for publication, March 20, 1950; accepted, June 26, 1950)

The availability of artificial isotopes of physiologically important elements has made possible measurement of the amount of these constituents in the living human body by application of the principle of isotope dilution. A known amount of isotope is administered and allowed to exchange with its naturally occurring brothers while its excretion is measured. When equilibrium is attained, the quantity of element in which the isotope is "diluted" is inversely proportional to the concentration of artificial isotope in natural isotopes (specific activity) of any body sample. This quantity of element we refer to as the body content of "exchangeable" element, which in the case of complete exchange is the total amount of element in the body. Development of methods for such chemical anthropometry is providing valuable new devices for investigation of physiologic and pathologic changes in man.

Early application of this principle to body water, sodium and potassium in this laboratory (1) led to the study now being reported. Attention was focussed on potassium (K) because of its important intracellular position and the availability of the short-lived radioactive isotope $K^{42}$ for human use. Simultaneously, further investigation of body water with deuterium oxide as

1 This work was carried out with the support of the Atomic Energy Commission under a contract between the Office of Naval Research and Harvard University and directly by the Atomic Energy Commission under a contract with the Peter Bent Brigham Hospital. This work was also supported in part by grants generously provided by Mead Johnson and Co., Winthrop Stearns, Inc., The Warren Benevolent Fund, The Ella Sachs Plotz Fund, and the Eugene Higgins Trust through Harvard University.

2 Milton Fellow, Harvard Medical School.

8 Henry E. Warren Fellow, Harvard Medical School; Assistant in Surgery, Peter Bent Brigham Hospital.

4 Moseley Professor of Surgery, Harvard Medical School; Surgeon-in-Chief, Peter Bent Brigham Hospital. tracer was carried out (2), and, independently, normal values of the exchangeable sodium in man were determined with $\mathrm{Na}^{24}$ in another laboratory (3).

The primary purposes of this study were to develop a method for the measurement of the amount of exchangeable potassium in the living human and to determine such values in healthy adult men. It became evident early that complete exchange was not attained during the period of observation afforded by safe tracer doses of $\mathrm{K}^{42}$ and that choice of a representative sample for analysis was a major problem. It was also evident that the significance of "normal" measurements would be enhanced by examination of the correlations that might exist with other body indices and that might permit extension of our data to studies of other healthy persons and pathologic states.

The body content of potassium is an anthropometric.value comparable to body weight, surface area or height and correlations with such measurements were investigated for possible clinical applications. Potassium on a weight basis is an extremely small fraction of the body, approximately $0.2 \%$, which assumes importance because it is the predominant cation of intracellular fluid. We should expect, then, to derive the greatest significance from studies of potassium in relation to intracellular water but present methods for measuring this phase of body water are indirect and difficult. Despite reservations cell water was estimated in this study as the difference between total body water and thiocyanate space. The almost exclusively intracellular position of potassium renders it probable that the body content of potassium is a good index of cellular mass. This possibility was explored by studying the correlations with total body water, basal oxygen con- 
sumption, plasma volume, and daily creatinine excretion.

In this paper are presented exchangeable potassium values for 30 healthy adult men, their correlations with other measurements indicated above, and an examination of underlying principles to clarify the meaning of exchangeable potassium measured by our method.

\section{EXCHANGEABLE POTASSIUM IN HEALTHY MALES}

\section{Experimental procedure}

The subjects were 30 white male college students, medical students and house officers from 21 to 32 years of age and in good health. After voiding they were given an intravenous injection of radioactive $K^{3}$ by calibrated syringe. All urine was collected at intervals for the next 40 to 60 hours and analyzed for radioactivity and potassium. A three hour morning "spot" urine sample was taken between 20 and 40 hours after an overnight fast while the subject was still fasting. At the time of this special voiding heparinized blood samples were taken from 16 subjects and separated into cells and plasma by centrifugation, protein-free filtrates of each being analyzed for radioactivity and potassium. There were no other restrictions on intake or activity.

\section{Radioactive potassium administration}

All $\mathrm{K}^{43}$ used in this study was obtained by air freight from Oak Ridge National Laboratories as potassium carbonate. ${ }^{5}$ Initial processing 6 included solution of the potassium carbonate in an equivalent amount of $1.0 \mathrm{~N}$ $\mathrm{HCl}$ with boiling. Sixty milliequivalents (meq.) were then diluted to $500 \mathrm{ml}$. with sterile water and to 1,000 $\mathrm{ml}$. with additional sterile isotonic saline to produce a final solution with cation concentrations:

\section{Potassium $60 \mathrm{meq} . / \mathrm{L}$. \\ Sodium 73 meq. $/ \mathrm{L}$.}

This was autoclaved and adjusted to $\mathrm{pH} 7.4$ with $\mathrm{HCl}$ before injection.

The radioactivity of this solution ranged from 100 to 300 microcuries per meq. $K$ at time of injection, ${ }^{6}$ the dose being about 100 microcuries ? (10-30 ml., 0.6-1.8

\footnotetext{
S Oak Ridge catalog no. 59.
}

- We are indebted to Dr. Arthur K. Solomon and the Biophysical Laboratory of the Harvard Medical School for processing of the dry "target" material in preparation for injection, and for absolute radioactivity measurements of the administered solution against a primary uranium oxide standard filtered with $20 \mathrm{mg} . / \mathrm{cm}$. paraffin as a basis for dosage.

7 The quantity of $\mathrm{K}^{*}$ based on delivery to tissue of 0.1 r.e.p. in the first 24 hours and calculated from Marinelli (4) is 1.9 microcuries per kilogram body weight, or 130 microcuries for a $70 \mathrm{~kg}$. man. This is well within accepted tolerances. Total body radiation from naturally occurring $\mathrm{K}^{\omega 0}$ is approximately 0.1 r.e.p. in three years. meq. $\mathrm{K}$ ). This was injected intravenously over a period of about five minutes (or taken orally with added water in three experiments). Except for occasional transient arm and shoulder aches along the course of the vein, there were no reactions to injection.

\section{Radioactivity measurements}

Radioactivity analyses were performed by evaporating to dryness in $10 \mathrm{ml}$. porcelain ashing dishes at least duplicate aliquots of the same solution used for potassium analysis, and counting activity with a lead-shielded sidewall Geiger tube and Tracerlab Autoscaler.8 Diluted aliquots of the injected solution were also read in quadruplicate at intervals during the counting for each experiment.

Radioactivity units were based on the counts delivered by an arbitrary uranium acetate standard. Correction was made for background which was usually about 50 counts per minute (c.p.m.) including 10-15 c.p.m. intrinsic in the porcelain dishes. Counting rates were generally high enough to have coefficients of variation below $2.5 \%$ and low enough so that no correction for resolving time was needed. Geometry was approximately $10 \%$ and was fixed. ${ }^{-}$Self-absorption by the amount of solids present in samples was undetectable. Over-all coefficient of variation for duplicate dishes of urine was about $2 \%$; for quadruplicate dishes of injected standard, less than $1 \%$. The Oak Ridge target decays with a half-life of 12.4 hours for about five days, before gradually assuming a half-life of about 20 days (probably rubidium 86 ). Since readings were made within five days, correction for decay was based on a half-life of 12.4 hours. However, contamination of the $\mathrm{K}^{\mathbf{3}}$ by rubidium 86 and an unidentified beta-emitter with approximately 50 hour half-life accounts for up to about $2 \%$ of the measured activity three days after removal from the pile; as further time passes the contribution to total activity made by these longerlived elements progressively increases. There was never enough $K^{\text {s0 }}$ present in samples to be significant. Sodium 24 contamination in the single shipment tested 10 amounted to only $0.05 \%$ of the total radiation.

\section{Chemical potassium determinations}

The cobaltinitrite precipitation method of Fiske and Litarzek (5) was used throughout, although occasional samples were also analyzed by flame photometer. Urine was analyzed directly. Plasma was treated as a protein-free filtrate prepared from one part plasma and one part 20\% trichloracetic acid; red cells were treated simi-

8 After this normal series had been completed it was found more satisfactory to measure the radioactivity of purified potassium samples on aluminum planchettes with an end window tube.

- Evaporation of 10-20 ml. of urine standards yielded 2-5\% higher readings than similar water standards, presumably because the solids decreased sample-to-countertube distance.

10 By uranyl zinc acetate precipitation at Dr. John Irvine's laboratory, Massachusetts Institute of Technology. 
larly in a dilution of one part washed cells, three parts water and one part $20 \%$ trichloracetic acid.

\section{Calculation of exchangeable potassium}

According to the principle of isotope dilution, the amount of exchanged potassium equals the amount of $\mathrm{K}^{\text {s }}$ in the body divided by the concentration of $\mathrm{K}^{42}$ in $\mathrm{K}^{20}$ in a body sample such as urine after equilibrium. ${ }^{11}$ The amount of isotope in the body is closely approximated here by subtracting the cumulative urinary excretion of tracer from the injected dose.

$$
K_{e}=\frac{K_{i}^{42}-K_{0}^{42}}{\frac{K_{u}{ }^{42}}{K_{u}{ }^{39}}}
$$

K. $\quad$ quantity of exchangeable potassium (meq.). $\mathbf{K}_{\mathbf{1}} \approx=$ radio-potassium administered (units).

11 The symbol " $\mathrm{K}^{20 "}$ is used throughout this paper to indicate naturally-occurring potassium $\left(\mathrm{K}^{39}, \mathrm{~K}^{40}, \mathrm{~K}^{41}\right)$ of average atomic weight 39.1 .
$\mathrm{K}_{0}{ }^{*}=$ radio-potassium excreted in urine to time of equilibrium sample (units).

$\mathrm{K}_{\mathbf{u}}$ = concentration of radio-potassium in urine samples (units/L.).

$\mathrm{K}_{\mathrm{u}}{ }^{29}=$ concentration of chemical potassium in urine samples (meq./L.).

$K_{u}{ }^{42} / K_{u}{ }^{39}=$ equilibrium urine specific activity (units/ meq.).

\section{Experimental error}

Variations intrinsic in the methods employed (syringing, radioactivity measurements, chemical determinations) could be expected to produce a random error of $5-7 \%$ in the measurement of exchangeable potassium based on a single urine determination. The use of duplicate determinations on multiple urines reduces this error to the order of $2-4 \%$ which is consistent with the reproducibility found in normal subjects (Table I).

The greatest single source of error was in radioactivity measurements; these errors may be reduced by elimination of extraneous solids with which were associ-

TABLE I

Exchangeable potassium in healthy men

Healthy male subjects

\begin{tabular}{|c|c|c|c|c|c|c|c|c|c|c|c|c|}
\hline $\begin{array}{c}1 \\
\text { Subj. }\end{array}$ & $\begin{array}{c}2 \\
\text { Date }\end{array}$ & $\begin{array}{c}3 \\
\text { Age }\end{array}$ & $\begin{array}{c}4 \\
\mathrm{Ht} .\end{array}$ & $\begin{array}{c}5 \\
\mathrm{~K}_{e}\end{array}$ & $\begin{array}{c}6 \\
\text { No. } \\
\text { obs. }\end{array}$ & $\begin{array}{c}7 \\
\text { Range }\end{array}$ & $\begin{array}{c}8 \\
\text { Wt. }\end{array}$ & $\begin{array}{c}9 \\
\mathrm{~K}_{\mathrm{e}} / \mathrm{Wt}\end{array}$ & $\begin{array}{c}10 \\
\text { Surface } \\
\text { Area }\end{array}$ & $\begin{array}{c}11 \\
\mathrm{~K}_{\mathrm{e}} / \mathrm{S} . \mathrm{A} .\end{array}$ & $\begin{array}{c}12 \\
\text { Basal } \mathrm{O}_{2}\end{array}$ & $\begin{array}{c}13 \\
\mathrm{~K}_{\mathrm{e}} / \mathrm{O}_{2}\end{array}$ \\
\hline $\begin{array}{l}\text { GF } \\
\text { JGr } \\
\text { VM } \\
\text { RF } \\
\text { JF } \\
\text { JS } \\
\text { BK } \\
\text { MS } \\
\text { GK } \\
\text { EL } \\
\text { CP } \\
\text { JC } \\
\text { DH } \\
\text { LK } \\
\text { WE } \\
\text { LL } \\
\text { JGa } \\
\text { DF } \\
\text { JH } \\
\text { DR } \\
\text { AP } \\
\text { RL } \\
\text { HM } \\
\text { JGo } \\
\text { AW } \\
\text { DB } \\
\text { FG } \\
\text { JP } \\
\text { RW } \\
\text { AG }\end{array}$ & $\begin{array}{r}3-15-49 \\
3-29-49 \\
4-12-49 \\
5-11-49 \\
4-12-49 \\
6-9-48 \\
4-12-49 \\
* \\
* \\
4-26-49 \\
10-27-48 \\
4-12-49 \\
* \\
5-11-49 \\
4-26-49 \\
3-29-49 \\
3-29-49 \\
* \\
2-8-49 \\
10-7-48 \\
* \\
2-8-49 \\
3-29-49 \\
2-8-49 \\
3-29-49 \\
3-29-49 \\
12-15-48 \\
4-12-49 \\
5-11-49\end{array}$ & $\begin{array}{l}y r s . \\
22 \\
30 \\
25 \\
27 \\
22 \\
25 \\
32 \\
23 \\
26 \\
24 \\
29 \\
25 \\
22 \\
22 \\
23 \\
27 \\
28 \\
24 \\
23 \\
21 \\
29 \\
25 \\
22 \\
29 \\
29 \\
29 \\
29 \\
21 \\
31 \\
30\end{array}$ & $\begin{array}{l}c m . \\
174 \\
165 \\
162 \\
182 \\
174 \\
176 \\
174 \\
178 \\
173 \\
182 \\
184 \\
179 \\
187 \\
178 \\
183 \\
172 \\
177 \\
189 \\
173 \\
169 \\
187 \\
178 \\
170 \\
172 \\
176 \\
173 \\
176 \\
178 \\
185 \\
198\end{array}$ & $\begin{array}{l}\text { meq. } \\
\text { Mean } \\
2770 \\
2840 \\
2960 \\
2960 \\
3000 \\
3020 \\
3070 \\
3120 \\
3180 \\
3210 \\
3220 \\
3290 \\
3360 \\
3370 \\
3380 \\
3390 \\
3500 \\
3590 \\
3600 \\
3640 \\
3660 \\
3720 \\
3740 \\
3750 \\
3760 \\
3800 \\
3820 \\
3900 \\
4040 \\
4470\end{array}$ & $\begin{array}{r}2 \\
4 \\
3 \\
5 \\
4 \\
5 \\
5 \\
6 \\
6 \\
10 \\
4 \\
5 \\
4 \\
10 \\
6 \\
5 \\
4 \\
4 \\
6 \\
4 \\
5 \\
8 \\
4 \\
4 \\
4 \\
4 \\
3 \\
7 \\
4 \\
6\end{array}$ & $\begin{array}{c}\% \text { Mean } \\
3.5 \\
4.9 \\
4.4 \\
9.1 \\
12.8 \\
24.8 \\
10.1 \\
* \\
* \\
* \\
5.6 \\
10.3 \\
3.6 \\
* \\
4.8 \\
8.9 \\
7.7 \\
3.9 \\
* \\
17.3 \\
24.0 \\
* \\
6.2 \\
4.8 \\
21.3 \\
13.1 \\
15.9 \\
18.2 \\
14.6 \\
11.2\end{array}$ & $\begin{array}{r}\text { kg. } \\
68.1 \\
66.5 \\
57.0 \\
75.5 \\
67.5 \\
65.0 \\
65.5 \\
65.0 \\
67.5 \\
69.5 \\
87.0 \\
70.5 \\
82.0 \\
70.0 \\
65.5 \\
74.5 \\
76.5 \\
84.5 \\
70.5 \\
71.0 \\
74.0 \\
70.5 \\
65.5 \\
77.5 \\
70.0 \\
78.5 \\
78.0 \\
81.0 \\
91.0 \\
125.5\end{array}$ & $\begin{array}{c}\text { meg./kg. } \\
40.7 \\
42.7 \\
51.7 \\
39.2 \\
44.5 \\
46.5 \\
46.9 \\
48.0 \\
47.1 \\
46.9 \\
37.0 \\
46.6 \\
41.0 \\
48.1 \\
51.6 \\
45.4 \\
45.7 \\
42.5 \\
51.9 \\
51.2 \\
49.5 \\
52.8 \\
57.1 \\
48.4 \\
53.6 \\
48.4 \\
49.1 \\
48.1 \\
44.3 \\
35.6\end{array}$ & $\begin{array}{l}m^{2} \\
1.81 \\
1.72 \\
1.59 \\
1.95 \\
1.80 \\
1.78 \\
1.78 \\
1.80 \\
1.79 \\
1.89 \\
2.09 \\
1.87 \\
2.06 \\
1.86 \\
1.84 \\
1.86 \\
1.92 \\
2.10 \\
1.83 \\
1.80 \\
1.97 \\
1.86 \\
1.75 \\
1.89 \\
1.85 \\
1.91 \\
1.93 \\
1.97 \\
2.14 \\
2.56\end{array}$ & $\begin{array}{c}\text { meq./m } \\
1530 \\
1650 \\
1860 \\
1520 \\
1670 \\
1700 \\
1720 \\
1740 \\
1780 \\
1730 \\
1540 \\
1760 \\
1630 \\
1820 \\
1840 \\
1820 \\
1820 \\
1710 \\
1970 \\
2020 \\
1860 \\
2000 \\
2140 \\
1980 \\
2030 \\
1990 \\
1980 \\
1980 \\
1880 \\
1680\end{array}$ & $\begin{array}{c}\text { L./hr. } \\
13.3 \\
10.7 \\
11.5 \\
\overline{14.5} \\
14.0 \\
14.0 \\
12.6 \\
13.4 \\
14.6 \\
15.4 \\
12.6 \\
14.6 \\
\overline{12.8} \\
13.1 \\
\overline{16.1} \\
14.0 \\
13.2 \\
12.7 \\
14.6 \\
\overline{-} \\
\overline{13.2} \\
15.7 \\
\overline{-} \\
\overline{14.2} \\
-\end{array}$ & $\begin{array}{c}\text { meg./L./ } \\
h r . \\
208 \\
265 \\
257 \\
- \\
207 \\
216 \\
219 \\
247 \\
235 \\
224 \\
209 \\
261 \\
230 \\
- \\
264 \\
259 \\
- \\
222 \\
258 \\
276 \\
288 \\
253 \\
- \\
- \\
285 \\
242 \\
- \\
284 \\
-\end{array}$ \\
\hline \multicolumn{2}{|l|}{ Mean } & & 177.5 & 3402 & & & 72.6 & 46.3 & 1.88 & 1810 & 13.6 & 242 \\
\hline \multicolumn{2}{|c|}{ Coeff. of variation } & & 16.2 & 10.2 & & & 10.4 & 9.3 & 6.4 & 10.5 & 9.4 & 10.5 \\
\hline \multicolumn{2}{|c|}{ Correlation coeff. } & & & & & & & 0.55 & & 0.45 & & 0.41 \\
\hline
\end{tabular}


TABLE I-Continued

Reproducibility

\begin{tabular}{|c|c|c|c|c|c|c|c|c|c|c|c|c|}
\hline $\begin{array}{c}1 \\
\text { Subj. }\end{array}$ & $\begin{array}{c}2 \\
\text { Date }\end{array}$ & $\begin{array}{c}3 \\
\text { Age }\end{array}$ & $\begin{array}{c}4 \\
\text { Ht. }\end{array}$ & $\begin{array}{c}5 \\
\mathrm{~K}_{0}\end{array}$ & $\begin{array}{l}6 \\
\text { No. } \\
\text { obs. }\end{array}$ & $\begin{array}{c}7 \\
\text { Range }\end{array}$ & $\begin{array}{c}8 \\
\mathrm{Wt} .\end{array}$ & $\begin{array}{c}9 \\
\mathrm{~K}_{\mathrm{e}} / \mathrm{Wt} .\end{array}$ & $\begin{array}{c}10 \\
\text { Surface } \\
\text { Area }\end{array}$ & $\begin{array}{c}11 \\
K_{\mathbf{e}} / \text { S.A. }\end{array}$ & $\begin{array}{c}12 \\
\text { Basal } \mathrm{O}_{2}\end{array}$ & $\begin{array}{c}13 \\
\mathrm{~K}_{\mathrm{e}} / \mathrm{O}\end{array}$ \\
\hline $\begin{array}{l}\text { LK } \\
\text { LK } \\
\text { LK }\end{array}$ & $\begin{array}{l}1-20-49 \\
2-2-49 \\
3-15-49\end{array}$ & $\begin{array}{r}y r s . \\
22 \\
22 \\
22\end{array}$ & $\begin{array}{r}c m . \\
178 \\
178 \\
178\end{array}$ & $\begin{array}{l}\text { meq. } \\
\text { Mean } \\
3390 \\
3320 \\
3400\end{array}$ & $\begin{array}{l}4 \\
4 \\
2\end{array}$ & $\begin{array}{c}\text { \% Mean } \\
6.8 \\
9.0 \\
10.6\end{array}$ & $\begin{array}{c}\mathrm{kg} . \\
70.0 \\
69.0 \\
71.0\end{array}$ & $\begin{array}{c}\text { meq. } / \mathrm{kg} . \\
48.4 \\
48.1 \\
47.9\end{array}$ & $\begin{array}{c}m^{2} \\
1.86 \\
1.84 \\
1.87\end{array}$ & $\begin{array}{c}\text { meq. } / m^{2} \\
1820 \\
1800 \\
1820\end{array}$ & L. $/ \mathrm{hr}$. & $\underset{h r .}{\operatorname{meq} . L . /}$ \\
\hline $\begin{array}{l}\text { MS } \\
\text { MS }\end{array}$ & $\begin{array}{l}2-1-49 \\
3-15-49\end{array}$ & $\begin{array}{l}23 \\
23\end{array}$ & $\begin{array}{l}178 \\
178\end{array}$ & $\begin{array}{l}3110 \\
3130\end{array}$ & $\begin{array}{l}5 \\
1\end{array}$ & $\stackrel{2.9}{-}$ & $\begin{array}{l}64.5 \\
65.5\end{array}$ & $\begin{array}{l}48.2 \\
47.8\end{array}$ & $\begin{array}{l}1.79 \\
1.80\end{array}$ & $\begin{array}{l}1740 \\
1740\end{array}$ & & \\
\hline $\begin{array}{l}\text { GK } \\
\text { GK }\end{array}$ & $\begin{array}{l}2-2-49 \\
3-15-49\end{array}$ & $\begin{array}{l}26 \\
26\end{array}$ & $\begin{array}{l}173 \\
173\end{array}$ & $\begin{array}{l}3150 \\
3210\end{array}$ & $\begin{array}{l}4 \\
2\end{array}$ & $\begin{array}{l}7.6 \\
5.9\end{array}$ & $\begin{array}{l}68.0 \\
67.0\end{array}$ & $\begin{array}{l}46.3 \\
47.9\end{array}$ & $\begin{array}{l}1.80 \\
1.78\end{array}$ & $\begin{array}{l}1750 \\
1800\end{array}$ & & \\
\hline $\begin{array}{l}\mathrm{JH} \\
\mathrm{JH}\end{array}$ & $\begin{array}{r}11-30-48 \\
3-15-49\end{array}$ & $\begin{array}{l}22 \\
23\end{array}$ & $\begin{array}{l}173 \\
173\end{array}$ & $\begin{array}{l}3620 \\
3570\end{array}$ & $\begin{array}{l}4 \\
2\end{array}$ & $\begin{array}{r}16.3 \\
1.0\end{array}$ & $\begin{array}{l}70.0 \\
71.0\end{array}$ & $\begin{array}{l}51.7 \\
50.2\end{array}$ & $\begin{array}{l}1.82 \\
1.83\end{array}$ & $\begin{array}{l}1990 \\
1950\end{array}$ & & \\
\hline $\begin{array}{l}\mathrm{RL} \\
\mathrm{RL}\end{array}$ & $\begin{array}{r}11-30-48 \\
3-15-49\end{array}$ & $\begin{array}{l}25 \\
25\end{array}$ & $\begin{array}{l}178 \\
178\end{array}$ & $\begin{array}{l}3690 \\
3750\end{array}$ & $\begin{array}{l}6 \\
2\end{array}$ & $\begin{array}{l}6.5 \\
5.9\end{array}$ & $\begin{array}{l}70.0 \\
71.0\end{array}$ & $\begin{array}{l}52.7 \\
52.8\end{array}$ & $\begin{array}{l}1.86 \\
1.86\end{array}$ & $\begin{array}{l}1980 \\
2020\end{array}$ & & \\
\hline $\begin{array}{l}\text { EL } \\
\text { EL } \\
\text { EL } \dagger\end{array}$ & $\begin{array}{l}10-27-48 \\
12-16-48 \\
4-26-49\end{array}$ & $\begin{array}{l}24 \\
24 \\
25\end{array}$ & $\begin{array}{l}182 \\
182 \\
182\end{array}$ & $\begin{array}{l}3380 \\
3140 \\
3100\end{array}$ & $\begin{array}{l}5 \\
5 \\
4\end{array}$ & $\begin{array}{l}20.7 \\
15.6 \\
10.0\end{array}$ & $\begin{array}{l}71.5 \\
67.5 \\
70.5\end{array}$ & $\begin{array}{l}47.2 \\
46.5 \\
44.0 \dagger\end{array}$ & $\begin{array}{l}1.91 \\
1.86 \\
1.89\end{array}$ & $\begin{array}{l}1770 \\
1690 \\
1640 \dagger\end{array}$ & & \\
\hline JGa & $\begin{array}{l}3-29-49 \\
4-26-49\end{array}$ & $\begin{array}{l}28 \\
28\end{array}$ & $\begin{array}{l}177 \\
177\end{array}$ & $\begin{array}{l}3500 \\
3310\end{array}$ & $\begin{array}{l}4 \\
2\end{array}$ & $\begin{array}{l}7.7 \\
1.0\end{array}$ & $\begin{array}{l}76.5 \\
75.5\end{array}$ & $\begin{array}{l}45.8 \\
43.8 \dagger\end{array}$ & $\begin{array}{l}1.92 \\
1.92\end{array}$ & $\begin{array}{l}1820 \\
1720 \dagger\end{array}$ & & \\
\hline $\begin{array}{l}\text { VM } \\
\text { VM } \dagger\end{array}$ & $\begin{array}{l}4-12-49 \\
4-26-49\end{array}$ & $\begin{array}{l}25 \\
25\end{array}$ & $\begin{array}{l}162 \\
162\end{array}$ & $\begin{array}{l}2960 \\
2520\end{array}$ & $\begin{array}{l}3 \\
3\end{array}$ & $\begin{array}{l}4.4 \\
4.8\end{array}$ & $\begin{array}{l}57.0 \\
55.5\end{array}$ & $\begin{array}{l}51.9 \\
45.4 \dagger\end{array}$ & $\begin{array}{l}1.59 \\
1.57\end{array}$ & $\begin{array}{l}1860 \\
1610 \dagger\end{array}$ & & \\
\hline
\end{tabular}

The table is divided into two parts, the second portion showing multiple determinations made on the same subjects, the first a summary of the values for all the subjects.

* Average of multiple determinations shown individually in Table I, Continued.

t Based on oral administration.

Columns $1-4$ are self-explanatory. In column 5 is shown the exchangeable potassium $\left(\mathrm{K}_{0}\right)$ in meq. The value shown is the mean value based on specific activities from a number of urine samples, the number of samples measured for specific activity being indicated in column 6 . In column 7 is shown the over-all range of exchangeable potassium values based on these urine activities, as \% of mean. In columns 8,10 and 12 are given the weight, surface area and the oxygen consumption, respectively, and in columns 9,11 and 13 are given the ratios of the $K_{0}$ and the adjoining index for each patient. The mean, coefficient of variation (standard deviation expressed as $\%$ of the mean) and correlation coefficient are given in the first portion of the table. With the exception of plasma volume (Table II) the correlation coefficients are significantly greater than zero but not significantly different from each other.

ated false high radioactivity readings. In some instances this error was found to be as much as $5 \%$ but was so variable that correction was not attempted.

\section{Correlated measurements}

Nude body weight and standing height were observed directly in all subjects and surface area obtained from a nomogram based on the formula of DuBois (6a). Total body water was determined by dilution of deuterium oxide in 12 subjects (2). Twenty-seven had thiocyanate space measurements by the method of Crandall and Anderson (7) modified for the Evelyn photoelectric colorimeter,12

12 Ten $\mathrm{ml}$. of a $5 \%$ solution of sodium thiocyanate was injected intravenously by calibrated syringe after withdrawal of a blood sample. Further samples were taken at approximately 40 and 60 minutes. A protein-free filtrate was made from one volume serum, four volumes water, and five volumes $10 \%$ trichloracetic acid. The color produced by adding five volumes of this proteinfree filtrate to one volume ferric nitrate reagent was read and seven had simultaneous measurements of plasma volume by the method of Gibson and Evelyn (8). Basal oxygen consumption was determined in 23 with BenedictRoth or Sanborn clinical apparatus, and 24 hour urine creatinine was measured in five by the method of Peters (9).

\section{Results}

The measurements of healthy male subjects are summarized in Tables I-III. In addition to all individual values the mean and coefficient of variation for the group are shown, with the exception that subject A. G. is not included in the statistical analysis because his measurements are far enough above the usual adult male range to skew

on an Evelyn colorimeter, using filter 515. Concentrations were determined from a standard curve prepared from known $\mathrm{NaSCN}$ solutions. 
TABLE II

Exchangeable potassium in healthy men

Healthy male subjects

\begin{tabular}{|c|c|c|c|c|c|c|c|c|c|}
\hline $\begin{array}{l}1 \\
\text { Subj. }\end{array}$ & $\underset{\mathrm{K}_{0}}{2}$ & SCNV & $\mathrm{K}_{\mathrm{e}} / \stackrel{4}{\mathrm{SCN}}$ & T.B.W. & Ke/T.B.W. & "IC" w. & $\mathrm{K}_{\mathrm{e}} / \mathrm{I}^{8} \mathrm{IC}^{\prime} \mathrm{W}$. & $\stackrel{9}{\text { Plasma vol. }}$ & $\mathrm{K}_{\mathrm{e}}^{10} / \mathrm{PV}$ \\
\hline $\begin{array}{l}\text { GF } \\
\text { VM } \\
\text { RF } \\
\text { JF } \\
\text { BK } \\
\text { MS } \\
\text { GK } \\
\text { EL } \\
\text { EL } \\
\text { CP } \\
\text { JC } \\
\text { DH } \\
\text { LK } \\
\text { WE } \\
\text { LL } \\
\text { JGa } \\
\text { DF } \\
\text { JH } \\
\text { DR } \\
\text { AP } \\
\text { RL } \\
\text { HM } \\
\text { JGo } \\
\text { AW } \\
\text { DB } \\
\text { FG } \\
\text { RW } \\
\text { AG }\end{array}$ & $\begin{array}{r}\text { meq. } \\
2770 \\
2960 \\
2960 \\
3000 \\
3070 \\
3110 \\
3150 \\
3380 \\
3140 \\
3220 \\
3290 \\
3360 \\
3370 \\
3380 \\
3390 \\
3500 \\
3590 \\
3620 \\
3640 \\
3660 \\
3690 \\
3740 \\
3750 \\
3760 \\
3800 \\
3830 \\
4040 \\
4470\end{array}$ & $\begin{array}{r}L . \\
14.9 \\
16.3 \\
18.3 \\
15.6 \\
18.4 \\
14.6 \\
14.5 \\
13.8 \\
14.9 \\
17.4 \\
13.9 \\
17.7 \\
18.7 \\
15.0 \\
16.5 \\
22.4 \\
17.4 \\
15.6 \\
15.2 \\
19.0 \\
17.3 \\
15.8 \\
19.0 \\
16.8 \\
18.8 \\
17.2 \\
21.6 \\
27.4\end{array}$ & $\begin{array}{l}\text { meq./L. } \\
186 \\
181 \\
162 \\
192 \\
167 \\
206 \\
217 \\
245 \\
211 \\
185 \\
237 \\
190 \\
181 \\
225 \\
205 \\
156 \\
206 \\
232 \\
239 \\
192 \\
213 \\
237 \\
197 \\
224 \\
202 \\
222 \\
187 \\
163\end{array}$ & $\begin{array}{c}L . \\
40.6 \\
- \\
\overline{-} \\
42.4 \\
39.9 \\
41.8 \\
- \\
- \\
- \\
45.8 \\
45.1 \\
46.0 \\
42.3 \\
46.9 \\
- \\
- \\
- \\
\overline{4} \\
49.3 \\
43.8 \\
- \\
- \\
-\end{array}$ & $\begin{array}{c}\text { meq./L. } \\
68.1 \\
= \\
= \\
72.5 \\
78.0 \\
75.4 \\
- \\
= \\
- \\
73.5 \\
75.0 \\
73.5 \\
80.1 \\
74.7 \\
= \\
- \\
- \\
- \\
86.4 \\
76.1 \\
86.0 \\
= \\
- \\
-\end{array}$ & $\begin{array}{c}L . \\
25.7 \\
- \\
\overline{-} \\
24.0 \\
25.3 \\
27.3 \\
- \\
- \\
- \\
28.1 \\
26.4 \\
31.0 \\
25.8 \\
24.5 \\
- \\
- \\
- \\
\overline{-} \\
27.5 \\
30.3 \\
27.0 \\
- \\
- \\
-\end{array}$ & $\begin{array}{c}\text { meq./L. } \\
108 \\
= \\
= \\
128 \\
123 \\
115 \\
= \\
= \\
- \\
119 \\
128 \\
109 \\
131 \\
143 \\
= \\
- \\
= \\
136 \\
124 \\
139 \\
- \\
- \\
-\end{array}$ & 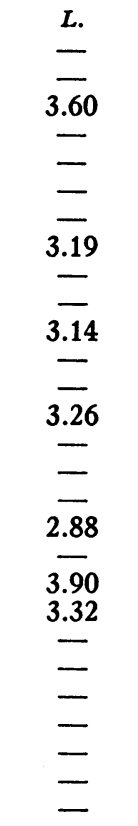 & $\begin{array}{c}\text { meq./L. } \\
\bar{Z} \\
\overline{825} \\
\bar{Z} \\
\overline{1} \\
1060 \\
\overline{-} \\
1050 \\
\overline{-} \\
\overline{1040} \\
\overline{-} \\
\overline{1} \\
\overline{1260} \\
\overline{938} \\
\overline{110} \\
\overline{-} \\
\overline{-} \\
\overline{-} \\
-\end{array}$ \\
\hline Mean & 3458 & 17.4 & 201 & 43.9 & 75.8 & 26.9 & 125 & 3.33 & 1050 \\
\hline $\begin{array}{l}\text { Coeff. of } \\
\text { variation }\end{array}$ & 9.9 & 15.5 & 9.9 & 6.3 & 7.4 & 7.3 & 8.6 & 11.2 & 13.2 \\
\hline $\begin{array}{c}\text { Correlation } \\
\text { coeff. }\end{array}$ & & & 0.46 & & 0.66 & & & & -0.11 \\
\hline
\end{tabular}

In columns 3,5, 7 and 9 are shown the thiocyanate volume of dilution, total body water (deuterium volume of dilution), the "intracellular" water volume determined as the difference between the total body water and the thiocyanate volume, and the plasma volume (Evans blue volume of dilution), respectively. In columns $4,6,8$ and 10 are given the ratios of the $K_{0}$ and the adjoining fluid volume. The mean, coefficient of variation and correlation coefficient are given, expressed as in Table I.

distribution considerably. In the weight range $55-95 \mathrm{~kg}$. exchangeable potassium varied from 2,770 to 4,040 meq. with a mean of 3,402 meq. and a coefficient of variation of 10.2. In all, 40 determinations are shown: 37 based on the intravenous administration of $\mathrm{K}^{42}$ and three based on oral ingestion of tracer. Of the former there are single determinations in 24 subjects, duplicate determinations in five, and triplicate values in one. Each measurement is the mean of two to ten figures based on an equal number of urine specific activity measurements between 20 and 50 hours after administration of $\mathrm{K}^{\mathbf{4 2}}$.

Reproducibility in the same subject expressed as the difference between duplicate determinations on a weight or surface area basis (Table I) has been within $4 \%$ of the mean which is consistent with that predicted on the basis of experimental accuracy. All three values based on oral administration are lower than similar results following intravenous injection in the same subject and are not included in the statistical analysis.

Correlations between exchangeable potassium and body weight, surface area, thiocyanate space, basal oxygen consumption, total body water, plasma volume, and 24 hour urine creatinine excretion are also included in Tables I-III. Ratios for each individual, coefficients of variation of the 
ratios and correlation coefficients for this series of associated measurements are shown in the tables.

\section{Discussion}

The ability to measure the amount of potassium in the human body has many potential applications in clinical investigation, most of which depend upon preliminary knowledge of the normal, healthy individual. The present study in healthy men was designed to yield such preliminary information in three principal areas: 1) clinical bases for accurate estimation of the potassium content of an individual, 2) the relationship of potassium, which is believed to be $98 \%$ intracellular, to other measurements thought to be related to cellular or "lean body" mass, and 3) the constancy of intracellular potassium concentration.

Although this group of healthy young men covered most of the usual adult range of weight, statistical analysis of their measurements (Tables I-III) provides objective evidence that we are dealing with a fairly homogeneous sample of the population, and that the variability among individuals is not much greater than the reproducibility of certain of our measurements. These facts initially limit attempts to show definitive relationships.

Exchangeable potassium content varies from 37.0 to 57.1 meq. $/ \mathrm{kg}$. body weight with the mean, 46.3 , and the coefficient of variation, 10.2. This mean is $20 \%$ below the previously accepted estimate for total body potassium of $58 \mathrm{meq} . \mathrm{kg}$.

TABLE III

Relation of exchangeable $K$ and urinary creatinine Healthy male subjects

\begin{tabular}{|c|c|c|c|}
\hline $\begin{array}{c}1 \\
\text { Subject }\end{array}$ & $\begin{array}{c}2 \\
\mathrm{~K}_{\mathrm{e}}\end{array}$ & $\begin{array}{c}3 \\
\text { Urine } \\
\text { creatinine }\end{array}$ & $\begin{array}{c}4 \\
\mathrm{~K}_{\mathrm{e}}\end{array}$ \\
\hline $\begin{array}{l}\text { JGa } \\
\text { JGo } \\
\text { DF } \\
\text { JGr } \\
\text { DB }\end{array}$ & $\begin{array}{l}\text { meq. } \\
3500 \\
3750 \\
3590 \\
2840 \\
3800\end{array}$ & $\begin{array}{c}\text { gm./day } \\
2.01 \\
2.23 \\
2.01 \\
1.66 \\
2.23\end{array}$ & $\begin{array}{c}\text { meq. } / g m . C / \\
\text { day } \\
1740 \\
1680 \\
1790 \\
1710 \\
1700\end{array}$ \\
\hline Mean & 3500 & 2.03 & 1724 \\
\hline $\begin{array}{l}\text { Coeff. of varia- } \\
\text { tion }\end{array}$ & 11.0 & 11.5 & 2.5 \\
\hline $\begin{array}{l}\text { Correlation } \\
\text { coeff. }\end{array}$ & & & 0.98 \\
\hline
\end{tabular}

TABLE IV

Correlation of exchangeable and chemical potassium Rabbits

\begin{tabular}{|c|c|c|c|c|c|c|c|}
\hline $\begin{array}{c}1 \\
\text { Exp. } \\
\text { No. }\end{array}$ & Wt. & $\begin{array}{c}3 \\
\underset{\mathbf{K}}{\text { Analytic }}\end{array}$ & $\begin{array}{c}4 \\
\text { Ex- } \\
\text { change- } \\
\text { able } \\
\mathbf{K}\end{array}$ & $\begin{array}{c}5 \\
\mathrm{~K} \\
\text { chem- } \mathrm{K}_{\mathrm{e}}\end{array}$ & \begin{tabular}{|c}
6 \\
Specific \\
activity \\
whole \\
rabbit
\end{tabular} & $\begin{array}{c}7 \\
\text { Specific } \\
\text { activity: } \\
\text { urine }\end{array}$ & $\begin{array}{c}8 \\
\text { Inj. } \mathrm{K}^{\mathbf{4 2}} \\
\text { re- } \\
\text { covered }\end{array}$ \\
\hline $\begin{array}{r}1 \\
2 \\
3 \\
4 \\
5 \\
6 \\
7 \\
8 \\
9 \\
10\end{array}$ & $\begin{array}{c}\text { kg. } \\
1.772 \\
1.006 \\
0.720 \\
0.808 \\
0.689 \\
1.002 \\
1.283 \\
1.282 \\
1.161 \\
0.833\end{array}$ & \begin{tabular}{|c|} 
meq. $/$ kg. \\
56.1 \\
61.1 \\
64.3 \\
48.5 \\
57.1 \\
57.9 \\
67.3 \\
65.0 \\
55.9 \\
52.6
\end{tabular} & \begin{tabular}{|c} 
meq. $/ \mathrm{kg}$. \\
54.2 \\
53.8 \\
58.8 \\
48.5 \\
59.8 \\
61.5 \\
59.6 \\
58.5 \\
52.6 \\
54.2
\end{tabular} & $\begin{array}{c}\text { meq. } / \mathrm{kg} . \\
1.9 \\
7.3 \\
5.5 \\
0 \\
-2.7 \\
-3.6 \\
7.7 \\
6.5 \\
3.3 \\
-1.8\end{array}$ & $\begin{array}{l}5.38 \\
5.3 \\
3.40 \\
2.01 \\
2.13 \\
2.82 \\
2.43\end{array}$ & $\begin{array}{l}u / \text { meq. } \\
1.75 \\
4.30 \\
4.6 \\
\\
5.5 \\
3.30 \\
2.15 \\
2.33\end{array}$ & $\begin{array}{l}105 \\
107 \\
103 \\
100 \\
101\end{array}$ \\
\hline & & 58.6 & 56.1 & +2 & & & \\
\hline
\end{tabular}

Columns 1-3 are self-explanatory. In column 4 is given the exchangeable potassium $\left(\mathrm{K}_{0}\right)$ calculated from specific activity of bladder urine at 40 hours, and in column 5 the differences between column 3 and column 4 . In column 7 is given the specific activity of the urine found in the bladder at the time of sacrifice ( 40 hours after injection) and in column 6 the specific activity of the entire digested animal. In column 8 is given the per cent of injected $\mathrm{K}^{42}$ found in the carcass, excreted urine and feces, and removed blood and tissue samples. The letter " $u$ " refers to arbitrary radioactivity units.

(10) which was based largely on animal data and agrees with our analytical figure for rabbits (Table IV). To find the closest correlation possible from our data the regression line of exchangeable potassium on body weight was calculated to be $\mathrm{K}_{\mathrm{e}}$ (meq.) $=1565+25.3 \mathrm{Wt}$. (kg.) ; having a standard error of estimate of $296 \mathrm{meq}$. or $8.7 \%$ of the mean and a correlation coefficient of 0.55 (Table I). This is considerably different from the direct ratio but the significance of this difference cannot yet be determined.

At best body weight can be only an approximate index of body potassium. Hastings (11), Rathbun and Pace $(12,13)$ and others have shown that the fat content of normal tissues and whole animals varies widely, and that certain chemical constituents, particularly water, bear a close relationship to fat-free weight. Since body fat in the human can be approximated only by difficult indirect methods, advantage was taken of this relationship with water to estimate the variability of exchangeable potassium on a fat-free weight basis by its correlation with total body water. The regression line $\mathrm{K}_{\mathrm{e}}$ (meq.) $=186+$ 72.4 T.B.W. (liters) has a standard error of esti- 
mate of 239 meq. or $7.1 \%$ of mean (correlation coefficient 0.66 ) but because the number of observations was only 12 , the confidence limits are greater than on the basis of body weight. The only close correlation was found with 24 hour urine creatinine, examined because it is thought to vary with the body muscle mass (6b) containing $60-70 \%$ of body potassium. The small sample size results in wide confidence limits but these data warrant further study.

We might expect that homeostatic mechanisms would act to maintain, a constant intracellular electrolyte pattern and that, despite possible variations of the pattern in different tissues, the mean concentration of potassium in intracellular water of normal individuals might be a constant. Experimental support of this hypothesis is exceedingly difficult to obtain. Intracellular water can at present only be estimated by difference between total body water $(1,2,14,15)$ and "extracellular" water. Although inulin appears the best available substance for measuring extracellular water (16), methods for its use are so cumbersome that they often preclude it. In healthy persons the thiocyanate space (7) seems related to extracellular water though certain cells such as erythrocytes, thyroid and gastric mucosa admit thiocyanate and produce an apparent volume of dilution that is about one-third greater than the inulin space (16). This relationship has been shown to be grossly changed in some diseases and is certainly open to question in all abnormal states (17). Despite these reservations dilution of thiocyanate is one of the practical methods for estimating extracellular water and, as such, was applied to the normal individuals in this study. Similarly the sodium space is probably a poor estimate of extracellular water, particularly in conditions affecting cell permeability to cations, but by this method the amount of exchangeable sodium in the body can also be measured $(1,3)$. Unsolved difficulties in the simultaneous use of $\mathrm{K}^{42}$ and $\mathrm{Na}^{24}$ did not permit use of the latter in this study. The estimated values for mean "intracellular" potassium concentration in 12 normal subjects (Table II) show a coefficient of variation of $7.3 \%$ about the mean 127 meq./L. "intracellular" water based on thiocyanate as extracellular. Calculations based on the inulin space $(0.66$ SCNV) as extracellular water yield a mean of
106 meq./L. which is probably nearer the true intracellular value.

We may conclude that the exchangeable potassium content of healthy individuals can be measured with good reproducibility, that body weight is in these preliminary studies a satisfactory basis for clinical estimation of potassium content in the normal and that other correlations should be sought over a wider range of measurements after certain improvements in present methods.

\section{EXAMINATION OF UNDERLYING PRINCIPLES}

The validity of isotope dilution methods for the measurement of body constituents depends upon adherence to certain fundamental conditions. First, the tracer should be treated by the body as though it were the traced. This precludes isotope effects, metabolic changes that the traced does not undergo, and toxicity. Second, at the time of measurement of equilibrium specific activity the tracer should be distributed throughout the body in direct proportion to the constituent being measured; i.e., the specific activity of all tissues should be identical. For practical purposes there should be readily available a body sample where this specific activity can be measured directly and the excretion rate of tracer should be easily measurable and small compared with its rate of exchange so that proportional distribution can be attained without excessive loss of tracer from the system. Each of these problems will be examined with respect to dilution of $\mathrm{K}^{42}$ as a measure of body potassium.

\section{Tracer properties of $K^{\mathbf{4 2}}$}

It has been shown for isotopes of low atomic weight, where addition of a neutron changes atomic weight considerably, that isotopes of the same element may be treated differently in both chemical and biological systems, especially if present in high concentration $(18,19)$. The extent of this "isotope effect" for $K^{42}$ seems minimal. Natural potassium is a mixture of $\mathrm{K}^{39}, \mathrm{~K}^{40}$ (naturally radioactive) and $K^{41}$ with an average atomic weight of 39.1 . Potassium 42 is only $7.4 \%$ greater in mass than this average mixture. Comparison of radioactivity of potassium from cadaver ashes and from pure laboratory reagents has shown that $\mathrm{K}^{40}$ is probably $1-2 \%$ less abundant in the former (20). On the other hand, study by mass 
spectrograph of the $\mathrm{K}^{41} / \mathrm{K}^{39}$ ratio in human tissues and laboratory reagents has revealed no difference in most tissues, slightly increased abundance of $\mathrm{K}^{41}$ in bone marrow and slightly decreased abundance in tumors (21). Such evidence from the naturally occurring isotopes suggests that differences in handling of $\mathrm{K}^{42}$ and natural $\mathrm{K}$ in the body are of little importance in isotope dilution experiments.

Metabolic destruction or production of tracer need not be considered in tracing an element by use of its own isotope. The physical change of radioactive decay in which $\mathrm{K}^{42}$ gradually becomes a chemically equivalent amount of naturallyoccurring non-radioactive calcium 42 is unimportant because the quantities involved are negligible.

The chemical toxicity of potassium is a potential danger in intravenous or oral administration but $0.5-2.0$ meq. injected slowly in adults at a concentration of $60 \mathrm{meq} . / \mathrm{L}$. (with sodium) has had no demonstrable ill effects. Studies on the lethal effect of rapid potassium administration were carried out in rabbits. Fatal outcome commenced when the infusion rate exceeded 0.025 meq. $/ \mathrm{kg} . / \mathrm{min}$.; between this level and 0.05 approximately half the rabbits died. Above 0.05 meq. $/ \mathrm{kg} . / \mathrm{min}$. practically all rabbits died. If directly translatable into terms of the $70 \mathrm{~kg}$. man, the danger level for sustained potassium injection is approximately $1.8 \mathrm{meq} . / \mathrm{min}$. Injections of short duration were made routinely in over 100 human subjects at one-quarter to one-third this rate.

The control of dosage in relation to radiation hazard has been mentioned in the section on radioactive potassium administration.

\section{Tissue distribution of $K^{42}$}

The problem of distribution is more complex. Early studies during the first 24 hours after injection of cyclotron-produced $\mathrm{K}^{\mathbf{4 2}}(22-25)$ had indicated that administered potassium was exchangeable with body potassium in rats, frogs, rabbits and cats but that rates of exchange varied widely in different tissues of the same animal. Species differences were small. In order to determine how nearly equilibrium could be reached using $\mathrm{K}^{42}$, specific activities of human and rabbit tissues and fluids were obtained up to 50 hours after administration.
Human tissues were obtained at operation in hospital patients at varying periods after injection. Small samples taken from the surgical specimen, biopsies of striated muscle, urine and protein-free filtrates of plasma and red cells were analyzed for radioactivity and potassium. Tissue analyses for potassium were done on $\mathrm{HCl}$ extracts of samples ashed in the porcelain dish used for radioactivity counting, but it was found later that variable amounts of potassium (from 0-15\%) remained in the dish despite prolonged extraction.

Rabbit tissues were obtained from growing rabbits of various strains and adult white Polish rabbits. They were injected intravenously with the same $\mathrm{K}^{\text {s2 }}$ solution used in humans, were kept in metabolic cages designed to collect all urine and feces without contamination by food, and were fasted for the final 24 hours. All excreta including cage washings were collected from time of injection until time of death and analyzed for radioactivity. At specified times rabbits were sacrificed with sodium nembutal or pentothal. Heparinized blood, bladder urine, and tissue samples were then removed and the remaining carcass ground and boiled in dilute nitric acid or dissolved in concentrated nitric acid. Bladder urine, proteinfree filtrates of plasma and red cells, acid extracts of tissues and carcass, and acid solutions of carcass were analyzed for radioactivity and potassium. Tissue extracts were prepared (26) by mixing minced tissue samples (about $5 \mathrm{gm}$.) with 10 volumes of $0.75 \mathrm{~N}$ nitric acid for one hour, filtering through a No. 7 Whatman filter paper, and washing to a volume of $100 \mathrm{ml}$.

These determinations (Figure 1 and Tables $\mathrm{V}$ and VI) show that injected $\mathrm{K}^{\mathbf{4 2}}$ is not distributed equally throughout all body potassium within 50

TABLE V

Erythrocyte specific activity

Healthy male subjects

\begin{tabular}{|c|c|c|c|c|c|}
\hline $\begin{array}{c}1 \\
\text { Subject }\end{array}$ & $\begin{array}{c}2 \\
\text { Hrs. } \\
\text { after inj. }\end{array}$ & $\begin{array}{c}3 \\
\text { Red cell } \\
\text { potassium }\end{array}$ & $\begin{array}{l}{ }^{4} \\
\text { Specific } \\
\text { activity: } \\
\text { red cells }\end{array}$ & $\begin{array}{c}5 \\
\text { Specific } \\
\text { activity: } \\
\text { urine }\end{array}$ & $\begin{array}{c}\text { Red cell/ } \\
\text { urine } \\
\text { ratio }\end{array}$ \\
\hline $\begin{array}{l}\text { RL-1 } \\
\text { RL-2 } \\
\text { JP } \\
\text { GF } \\
\text { JH } \\
\text { LK } \\
\text { MS } \\
\text { GK }\end{array}$ & $\begin{array}{l}39.8 \\
38.3 \\
38.3 \\
40.2 \\
40.2 \\
40.6 \\
43.3 \\
40.1\end{array}$ & $\begin{array}{c}\text { meq./L. } \\
\text { cells } \\
99 \\
98 \\
107 \\
105 \\
100 \\
106 \\
103 \\
98\end{array}$ & $\begin{array}{l}\text { units/meq. } \\
0.24 \\
0.052 \\
0.29 \\
0.065 \\
0.059 \\
0.046 \\
0.060 \\
0.053\end{array}$ & $\begin{array}{l}\text { units } / \text { meq. } \\
0.38 \\
0.074 \\
0.36 \\
0.102 \\
0.074 \\
0.084 \\
0.083 \\
0.088\end{array}$ & $\begin{array}{l}0.63 \\
0.70 \\
0.80 \\
0.64 \\
0.80 \\
0.55 \\
0.72 \\
0.60\end{array}$ \\
\hline Mean & & 102 & & & 0.69 \\
\hline \multicolumn{2}{|c|}{ Coeff. of variation } & 3.3 & & & 11.5 \\
\hline
\end{tabular}

In column 2 is indicated the number of hours after injection the samples were taken. Column 3 shows the potassium content of the cells. Column 4 shows specific activity of the cells and column 5 that of the urine. Column 6 is the ratio of column 4 to column 5 . 
TABLE VI

Tissue specific activity

Rabbits

\begin{tabular}{|c|c|c|c|c|c|c|c|c|c|c|c|}
\hline \multirow{2}{*}{$\begin{array}{c}1 \\
\text { Rabbit } \\
\text { No. }\end{array}$} & \multirow{2}{*}{$\begin{array}{c}2 \\
\text { Hrs. } \\
\text { after } \\
\text { inj. }\end{array}$} & \multicolumn{2}{|c|}{ Kidney } & \multicolumn{2}{|c|}{ Liver } & \multicolumn{2}{|c|}{ Muscle } & \multicolumn{2}{|c|}{ Heart } & \multicolumn{2}{|c|}{ Brain } \\
\hline & & $\begin{array}{c}3 \\
\mathbf{K} \text { cont. }\end{array}$ & $\begin{array}{l}\text { 4 } \\
\text { Rel. } \\
\text { sp. act. }\end{array}$ & $\begin{array}{c}5 \\
\mathbf{K} \text { cont. }\end{array}$ & $\begin{array}{c}6 \\
\text { Rel. } \\
\text { sp. act. }\end{array}$ & $\begin{array}{c}7 \\
\mathrm{~K} \text { cont. }\end{array}$ & $\begin{array}{c}8 \\
\text { Rel. } \\
\text { 8p. act. }\end{array}$ & $\begin{array}{c}9 \\
\mathrm{~K} \text { cont. }\end{array}$ & $\begin{array}{c}10 \\
\text { Rel. } \\
\text { sp. act. }\end{array}$ & $\begin{array}{c}11 \\
\text { K cont. }\end{array}$ & $\begin{array}{c}12 \\
\text { Rel. } \\
\text { sp. act. }\end{array}$ \\
\hline 35 & 22 & $\begin{array}{c}\text { meq. } / \mathrm{kg} . \\
65 \\
65\end{array}$ & $\begin{array}{l}0.88 \\
0.89\end{array}$ & $\begin{array}{c}\text { meq. } / \mathrm{kg} . \\
69 \\
64\end{array}$ & $\begin{array}{l}0.81 \\
1.07\end{array}$ & $\begin{array}{c}\text { meq. } / \mathrm{kg} . \\
104 \\
104\end{array}$ & $\begin{array}{l}1.04 \\
1.00\end{array}$ & $\begin{array}{c}\text { meq. } / \mathrm{kg} . \\
63\end{array}$ & 0.96 & $\begin{array}{c}\text { meq. } / \mathrm{kg} . \\
86\end{array}$ & 0.49 \\
\hline 32 & 24 & $\begin{array}{l}61 \\
64\end{array}$ & $\begin{array}{l}1.00 \\
0.94\end{array}$ & $\begin{array}{l}72 \\
66\end{array}$ & $\begin{array}{l}1.08 \\
1.31\end{array}$ & $\begin{array}{l}90 \\
96\end{array}$ & $\begin{array}{l}1.00 \\
1.02\end{array}$ & 20 & & 71 & 1.66 \\
\hline 37 & 26 & $\begin{array}{l}54 \\
52\end{array}$ & $\begin{array}{l}0.88 \\
0.84\end{array}$ & $\begin{array}{l}57 \\
63\end{array}$ & $\begin{array}{l}0.83 \\
0.77\end{array}$ & $\begin{array}{r}98 \\
100\end{array}$ & $\begin{array}{l}0.84 \\
0.93\end{array}$ & 79 & 0.72 & 75 & 0.20 \\
\hline 36 & 38 & $\begin{array}{l}61 \\
69\end{array}$ & $\begin{array}{l}1.08 \\
0.91\end{array}$ & $\begin{array}{l}74 \\
71\end{array}$ & $\begin{array}{l}0.98 \\
0.99\end{array}$ & $\begin{array}{r}98 \\
104\end{array}$ & $\begin{array}{l}1.11 \\
1.03\end{array}$ & 66 & 1.11 & 65 & 0.29 \\
\hline 29 & 42 & $\begin{array}{l}81 \\
57\end{array}$ & $\begin{array}{l}0.34 \\
0.93\end{array}$ & $\begin{array}{l}61 \\
77\end{array}$ & $\begin{array}{l}0.82 \\
0.89\end{array}$ & 138 & 0.79 & 51 & 0.89 & 73 & 0.60 \\
\hline 34 & 42 & $\begin{array}{l}51 \\
54\end{array}$ & $\begin{array}{l}1.06 \\
0.98\end{array}$ & $\begin{array}{l}60 \\
59\end{array}$ & $\begin{array}{l}0.99 \\
0.95\end{array}$ & $\begin{array}{r}98 \\
104\end{array}$ & $\begin{array}{l}1.08 \\
0.97\end{array}$ & 43 & 2.9 & 63 & 1.22 \\
\hline 30 & 44 & $\begin{array}{l}52 \\
58\end{array}$ & $\begin{array}{l}1.22 \\
1.03\end{array}$ & $\begin{array}{l}65 \\
63\end{array}$ & $\begin{array}{l}1.15 \\
1.13\end{array}$ & $\begin{array}{r}95 \\
107\end{array}$ & $\begin{array}{l}1.12 \\
1.00\end{array}$ & 53 & 1.24 & 69 & 0.49 \\
\hline
\end{tabular}

In column 2 is given the time of tissue sampling in hours after the injection of a tracer dose of $\mathrm{K}^{\mathbf{2}}$. In the following columns are given the tissue chemical potassium concentration as meq. $/ \mathrm{kg}$. of wet tissue and the ratios of the specific activity of the tissue to the specific activity of the urine. When the specific activities are the same, this ratio is 1.0 . When the tissue specific activity is higher, the ratio is above 1.0; when lower, below 1.0 .

hours. In the human as in animals studied earlier by Fenn (25) exchange with plasma potassium is rapid in liver, slower in muscle and still slower in red cells and presumably brain and bone. Furthermore, there are no great differences in exchange rates between rabbit and human so that much of what can be learned from rabbit experiments seems applicable to man. From these tissue data and a knowledge of chemical potassium distribution in the body (10) we can estimate that at 20 hours about $10 \%$ of body potassium has not exchanged with tracer and that at 40 hours about $5 \%$ remains unexchanged.

This failure to reach proportional distribution signifies that the values and meaning of "exchangeable" potassium depend on the time and the source of the sample. Three readily available sources of body potassium were studied: plasma, erythrocyte, and urine. The hope that the erythrocyte, as the only easily sampled cell, might reflect overall cell exchange has proven incorrect $^{18}$ (Figure 1). The circulating plasma

13 During initial studies (1), erythrocyte specific activity was used for the calculation of exchangeable po- might logically be expected to represent over-all exchange but the quantity of potassium available is so small that accurate radioactivity readings using safe tracer doses of $\mathrm{K}^{\mathbf{4 2}}$ are difficult. The similarity between curves of plasma and urine specific activity versus time after injection led at once to detailed investigation of urine as the sample.

\section{Urine potassium as representative body sample}

Urine specific activity not only seemed to mirror plasma specific activity but urine potassium was easily available, usually in high concentration and sufficient quantity for precise measurement (Table VII). The renal excretion of potassium is believed to be a combination of glomerular filtration, absorption in proximal tubules, and secretion from distal tubules (27). Urine potassium obtained soon after injection of $\mathrm{K}^{42}$ might, therefore, be of lower specific activity than simultaneous plasma potassium because of "wash-out" tassium. As experience accumulated it became clear that figures so derived would be $20-40 \%$ high due to this slowly-exchanging property of the red cell. 
TABLE VII

Urinary excretion of potassium

Healthy male subjects

\begin{tabular}{l|c|c|c}
\hline \hline & $\begin{array}{c}1 \\
\text { Concentration }\end{array}$ & $\begin{array}{c}2 \\
\text { Excretion rate }\end{array}$ & $\begin{array}{c}\text { Excretion rate } \\
\text { (spot voiding) }\end{array}$ \\
\cline { 1 - 2 } Mean & meq./L. & meq. $/ \mathrm{hr}$. & meq. $/ \mathrm{hr}$. \\
Range & 64 & 3.2 & 2.3 \\
& $4-196$ & $0.6-9.7$ & $0.9-6.1$ \\
\hline
\end{tabular}

of natural tubule potassium, or later might show higher specific activity than plasma if the rate of exchange was such that early high plasma activity was retained by renal tubules after the plasma level had dropped. However, since the amount of potassium in normal kidneys is about 15 meq. (10) whereas glomerular filtration alone accounts for turnover of about 750 meq./day, the rapid approach of renal specific activity to plasma specific activity observed in the rabbit might have been anticipated.
Another possible source of difference between plasma and urine was exchange across the bladder wall. We have been unable to demonstrate any such exchange following introduction of radiopotassium into the catheterized human bladder but have secured quantitative recovery of instilled $\mathrm{K}^{42}$ from the bladder after several hours, with no detectable radioactivity in plasma. Bladder, ureteral, and renal pelvic residual can also introduce errors, particularly soon after injection.

Despite these considerations which may cause small differences between plasma and urine specific activities during the early hours of equilibration, we have no evidence to support any subsequent variation. In fact, late simultaneous plasma and urine specific activities have agreed within the accuracy of plasma readings (Table VIII).

Examination of the urine specific activity curve in Figure 1 reveals that it approaches a nearly constant value at about the same time that the

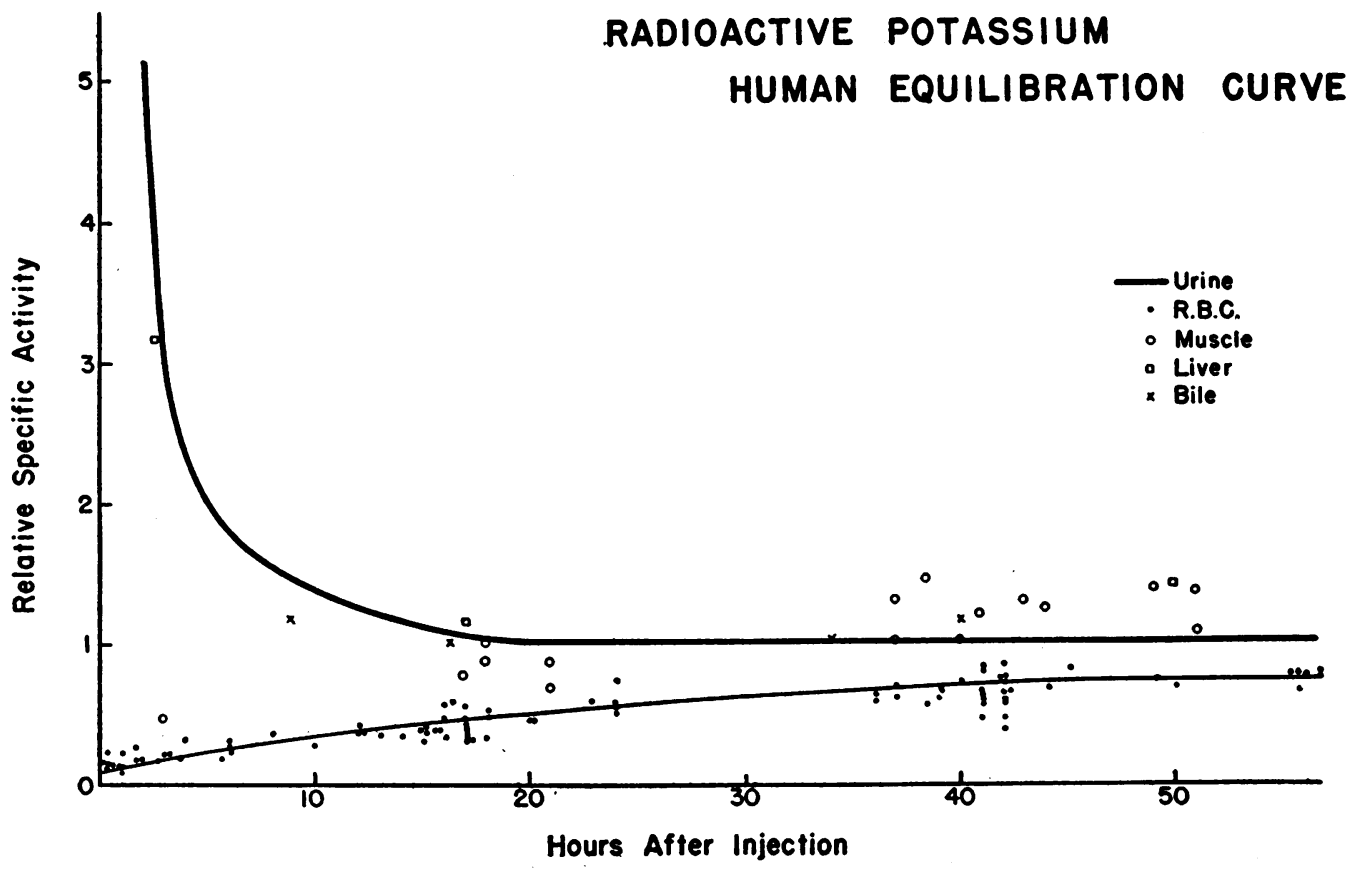

Fig. 1. Relative Specific Activities of Urine and Tissues

These data were obtained from hospital patients following intravenous administration of $\mathrm{K}^{\mathrm{a}}$ at time zero. "Relative specific activity" is the observed value divided by the equilibrium urine value to provide a common scale. The urine curve is a smoothed line through 113 observations in nine patients. A similar line is drawn through the erythrocyte data. Muscle and liver points represent the experimental values and are not corrected for the variable error of the tissue analyses. These were found later to yield specific activities $0-15 \%$ higher than the true values. A line through the corrected muscle points would reach the equilibrium urine value at approximately 25 hours and remain at that level. 
TABLE VIII

Plasma vs. urine specific activity Patients

\begin{tabular}{l|c|c|c}
\hline $\begin{array}{c}1 \\
\text { Patient }\end{array}$ & $\begin{array}{c}2 \\
\text { Date }\end{array}$ & $\begin{array}{c}\text { Specific activity: } \\
\text { urine }\end{array}$ & $\begin{array}{c}4 \\
\text { Specific activity: } \\
\text { serum }\end{array}$ \\
\hline & & units/meq. & units/meq. \\
M.R. (1) & $1-25-50$ & 0.145 & 0.143 \\
M.R. (2) & $2-7-50$ & 0.158 & 0.152 \\
J.D. & $2-15-50$ & 0.281 & 0.283 \\
L.K. & $2-15-50$ & 0.531 & 0.526 \\
\hline
\end{tabular}

In columns 3 and 4 are given the comparative specific activities of urine and plasma collected 24-27 hours after intravenous injection of $\mathrm{K}^{42}$. The urine value is the mean of three samples collected at hourly intervals, the serum value is of one sample collected at the time of voiding of the first urine sample.

large mass of muscle potassium approaches the same value. Similarly, urine specific activity in normal subjects (Figure 2) reaches within 20 hours a slowly decreasing value which the ex- perimental data cannot distinguish from the decrease expected on the basis of replacement of excreted tracer with ingested natural potassium. However, animal and human data indicate that even at 40 hours after injection, erythrocyte, brain and bone (25) potassium, comprising about $15 \%$ of the total body potassium, have a specific activity about $70 \%$ that of urine. Theoretically, if the remaining $85 \%$ of body potassium at that time had a mean specific activity $5 \%$ above the simultaneous urine value, urine specific activity would exactly equal the mean body specific activity. Experimentally, specific activity of muscle, liver, kidney, and heart are nearly equal ${ }^{14}$ to that of simultaneous urine after 20 hours.

14 Our present cumulative error, in the determination of tissue specific activity, is not less than $10 \%$, and final evaluation must await improvement of tissue techniques.

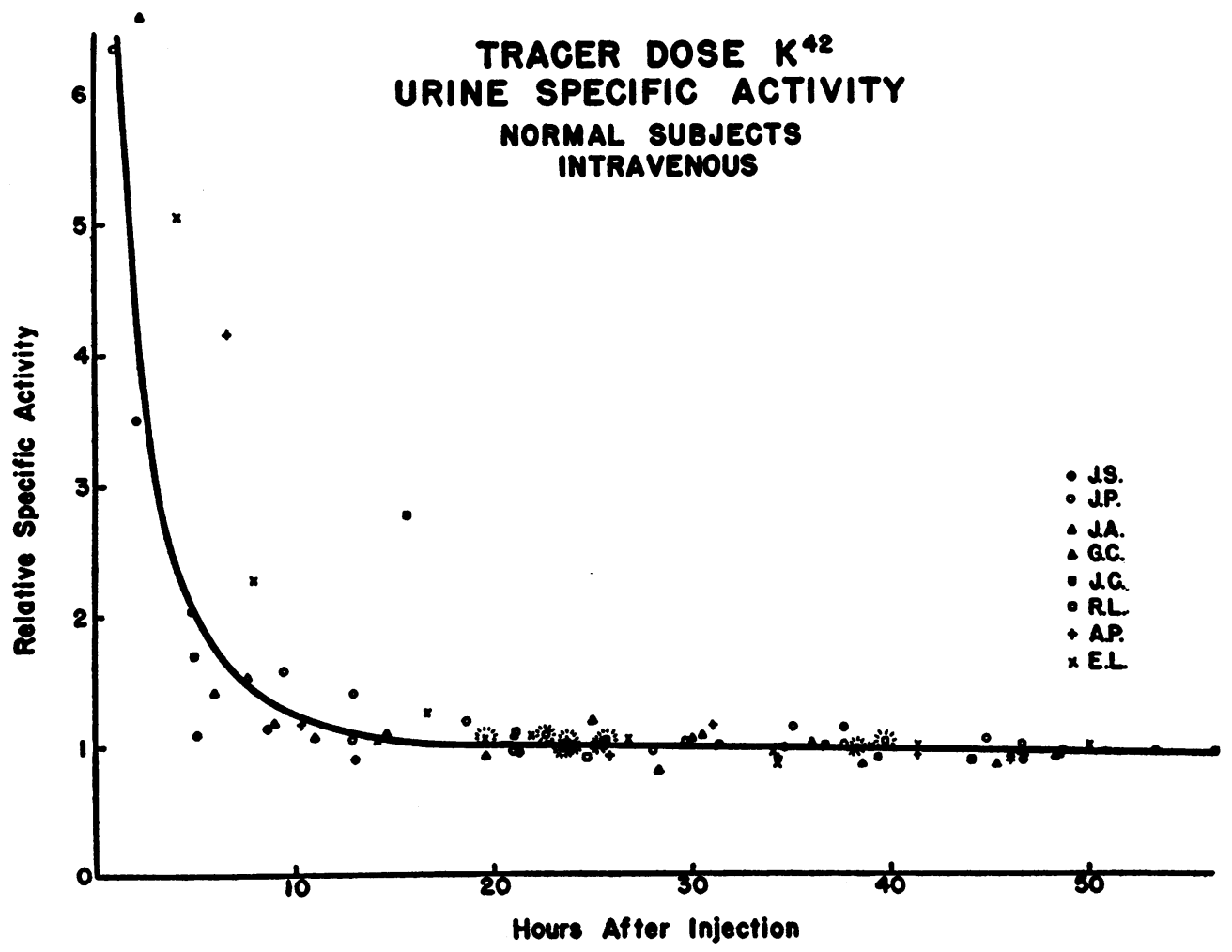

Fig. 2. Urine Specific Activity in Healthy Young Men

(Intravenous Administration)

Coordinates are the same as in Figure 1. Data are plotted at the time of voiding (rather than at the mid-point of the collection period) although the period of collection extended from time zero initially and from the previous time of voiding thereafter. The starred points represent fasting "spot" voidings.

. Data from duplicate experiments are included for subjects EL and JP. 


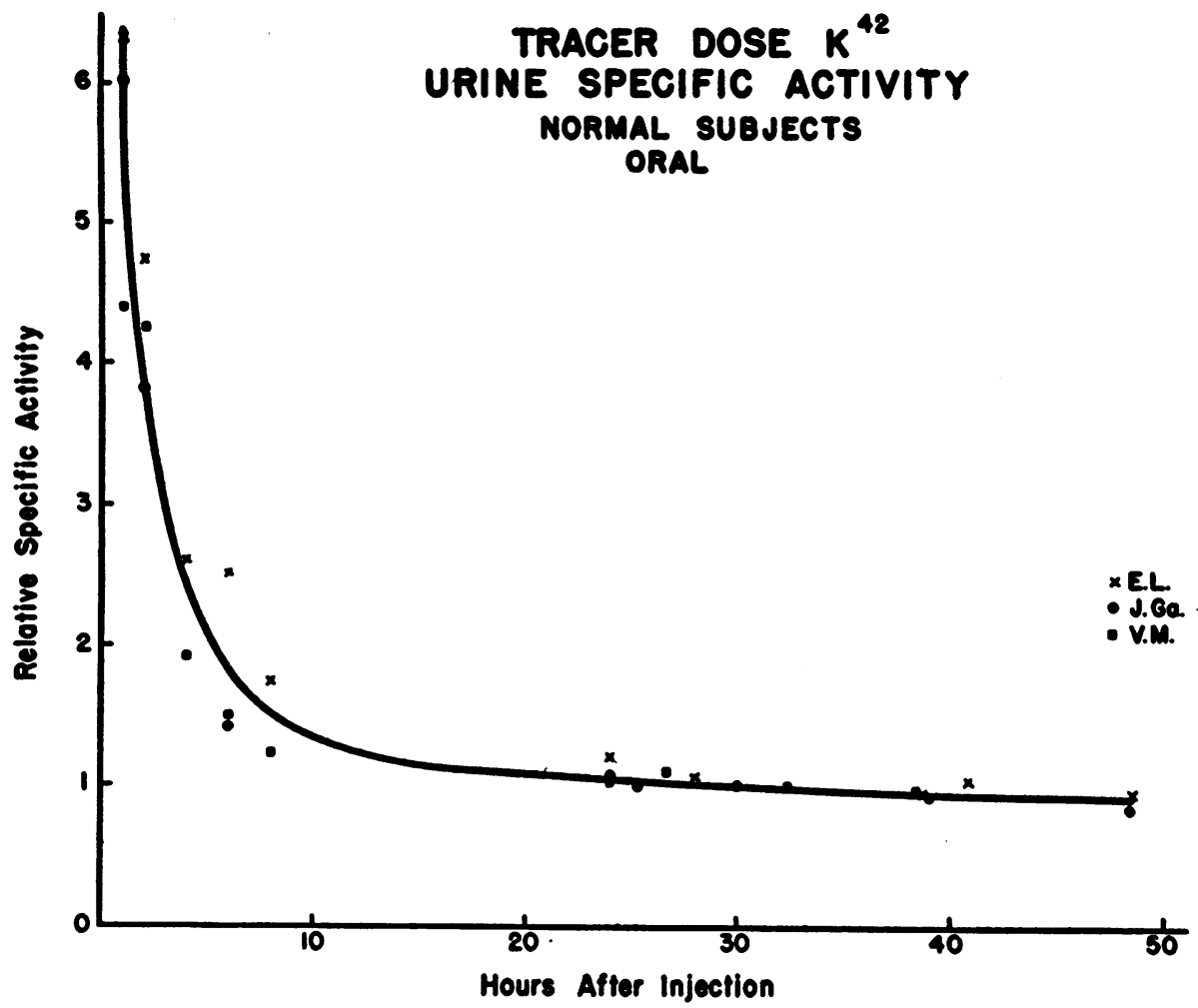

Fig. 3. Urine Specific Activity in Healthy Young Men

(Oral Administration)

Coordinates are the same as in Figure 1. Data are plotted at the time of voiding (rather than at the mid-point of the collection period) although the period of collection extended from time zero initially and from the previous time of voiding thereafter.

TABLE IX

Source of urinary potassium

Healthy male patients

\begin{tabular}{|c|c|c|c|c|}
\hline \multirow{2}{*}{ Subject } & \multirow{2}{*}{$\mathrm{K}$ ingested } & \multirow{2}{*}{$\frac{3}{\underbrace{\text { Urinary } K}_{\text {Output }}}$} & \multicolumn{2}{|c|}{$\begin{array}{c}4 \text { and } 5 \\
\text { Urinary } K \text { source } \\
\text { (\% of total excreted) }\end{array}$} \\
\hline & & & Dietary & Body stores \\
\hline $\begin{array}{l}\text { JT (1) } \\
\text { DS (2) } \\
\text { AS (3) } \\
\text { JH (4) } \\
\text { WH (5) }\end{array}$ & $\begin{array}{r}\text { meq. } \\
8.4 \\
12.8 \\
62.4 \\
64.2 \\
66.8\end{array}$ & $\begin{array}{r}\text { meq. } \\
9.3 \\
8.9 \\
51.0 \\
42.7 \\
10.6\end{array}$ & $\begin{array}{l}0.2 \\
0.7 \\
6.5 \\
8.4 \\
6.6\end{array}$ & $\begin{array}{l}99.8 \\
99.3 \\
93.5 \\
91.6 \\
93.4\end{array}$ \\
\hline
\end{tabular}

Column 2 shows the amount of chemical potassium ingested with the tracer dose of $K^{4}$. In column 3 is shown the potassium excreted in the six hours following ingestion. In columns 4 and 5 are shown the meq. of $K$ excreted in the urine according to the source (dietary or body stores); this is calculated from the per cent of tracer excreted in the six hours of the experiment. It is readily seen (column 4) that with high dietary intakes (subjects 3,4 and 5), there is an increase in both relative and absolute representation in urine $K$ of the recently ingested dietary $K$.
A final test of the relationship between urine and whole body specific activity would be the direct comparison of these values in animals. As shown in Table IV the total carcass specific activity does correspond to urine specific activity at 40 hours; and, by corollary, the exchangeable potassium is the same as the total chemical potassium within about $5 \%$, the approximate analytic error of the method.

It might be expected on the basis of plasmatissue exchange data that orally administered potassium would not come into equilibrium with the total body pool before some of it was excreted. If so, both plasma and urine specific activities might have postprandial values. significantly lower than the body average. Two methods were used to explore this possibility.

(1). Measurement of early urine specific activity after oral $\mathrm{K}^{42}$ administration in three normal subjects (Figure 3 ) and five hospital patients (Table 
IX) showed directly that there was disproportionately large excretion of recently ingested potassium usually (but not always) increasing with the oral potassium load.

(2). Measurement of late urine specific activity in three hospital patients previously given intra- venously $K^{42}$ while on low potassium diets and suddenly given a five-fold increase in oral potassium showed little change (Figure 4). Similarly no correlation was found between rate of potassium excretion and urine specific activity 20 to 50 hours after $\mathrm{K}^{42}$ injection in one hundred sam-
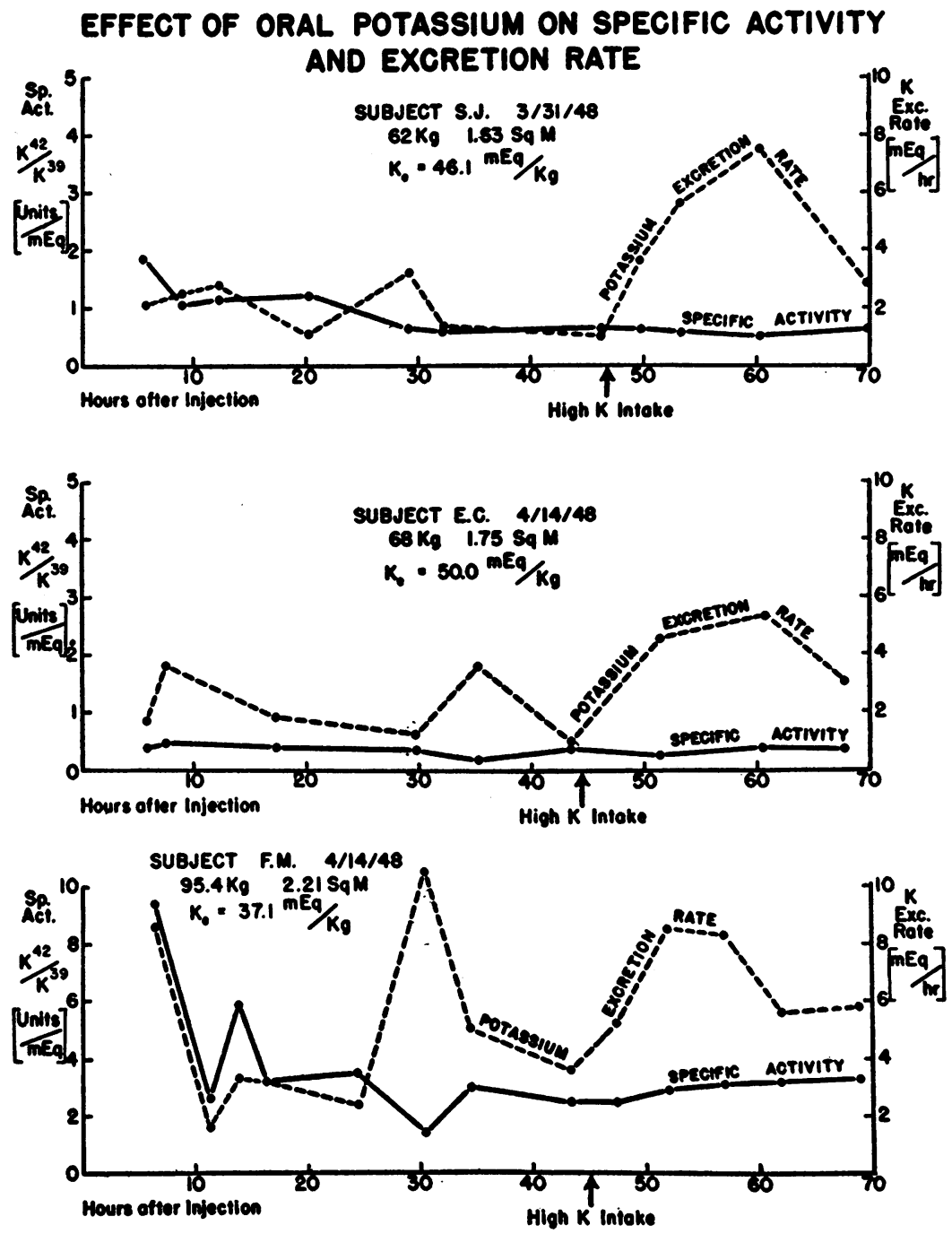

Fig. 4. Efrect of Oral Potassium on Urine Specific Activity

Three hospital patients, S. J. (infected finger), E. C. (convalescent, hernia repair) and F. M. (convalescent, ligated varicose veins), were maintained on diets containing about 20 meq. $\mathrm{K}$ per day before and after injection of $\mathrm{K}^{2}$ at time zero. At approximately 45 hours (arrows) the oral potassium intake was suddenly increased to over 150 meq. during the subsequent 24 hours. At this time subject S. J. accidentally drank 50 meq. $\mathrm{K}$ (as $25 \% \mathrm{KCl}, 3,500$ meq. $\mathrm{K} / \mathrm{L}$.) before eating and within a few minutes experienced nausea, vomiting, palpitation, sweating, and weakness which subsided in ten minutes with no treatment except oral isotonic saline. Later he tolerated a similar supplement following a meal with no symptoms. 


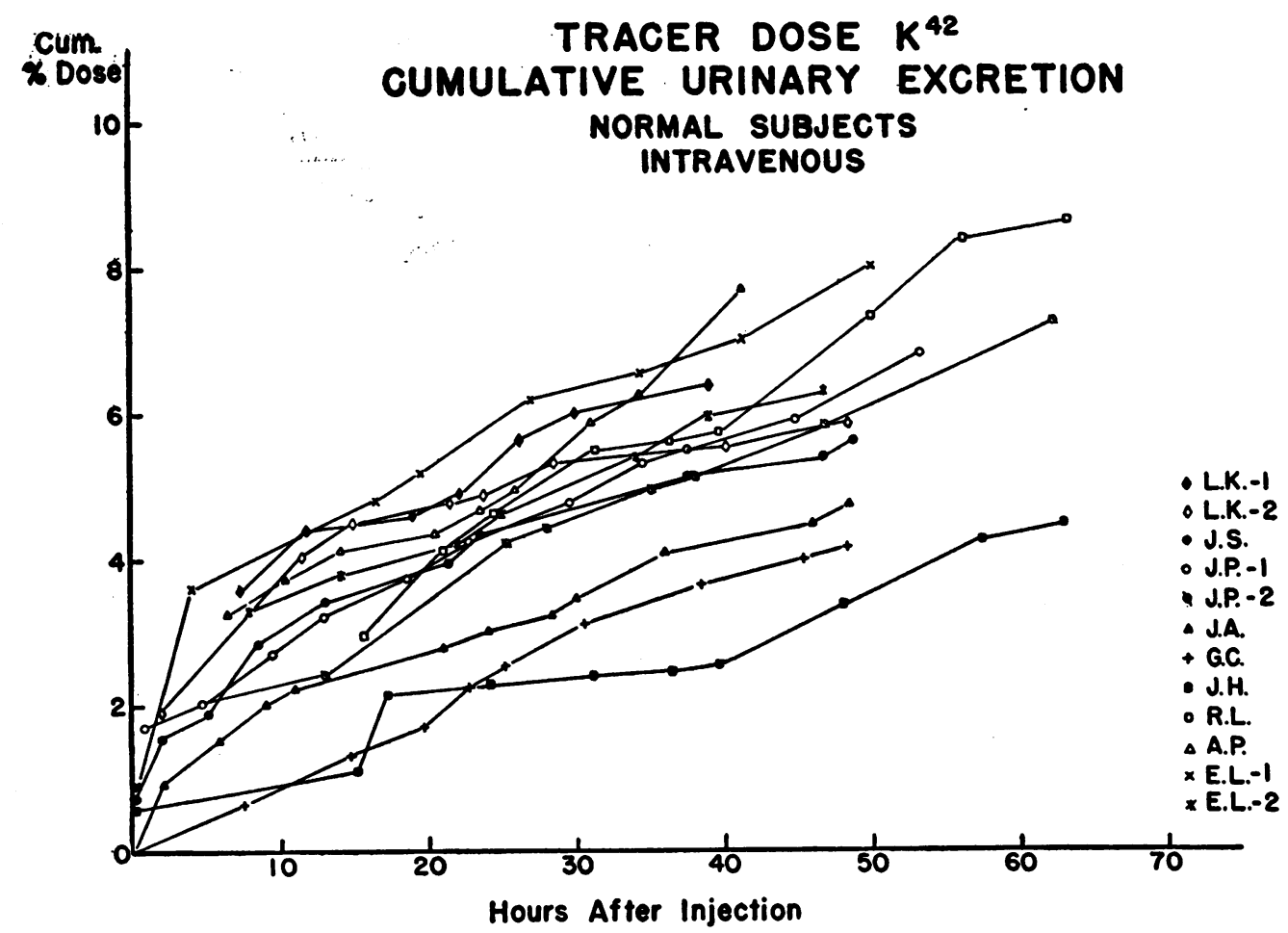

Fig. 5. Cumulative Urinary Excretion of $\mathrm{K}^{3}$ in Healthy Men

Approximately 100 microcuries $\mathrm{K}^{23}$ in 1.5 meq. $\mathrm{K}$ were administered intravenously at time zero. The mean 24 hour excretion between 20 and 60 hours is $2.3 \%$ of dose. The total excretion in 40 hours varied in these nine subjects from 2.5 to $7.5 \%$ of dose which is also the maximum range observed in all 30 healthy young men studied.

ples from the healthy male subjects, and no significant difference was detected between fasting "spot" and regular voidings (Figure 2).

These data indicate that high oral potassium intake may on occasion lower specific activity in the urine. For this reason an overnight fast is judicious before taking a urine sample for analysis. The apparently conflicting fact that increases in potassium excretion rate following oral ingestion are accompanied by minimal changes in urine specific activity may be accounted for by the small amount of potassium ingested relative to the quantity with which it is exchanged before excretion.

\section{Excretion of $K^{42}$}

Potassium is excreted by the body normally by three routes: urine, feces, and sweat. Balance studies on healthy adult males indicate that renal excretion is about $85-95 \%$ of the total, fecal 5$15 \%$, and sweat, unless excessive, less than $3 \%$
(28). With gastrointestinal disorders excretion in feces, vomitus or drainage may be larger and in severe fever the sweat loss may be as much as 1 meq./hour (29). Since the average adult in balance takes in and excretes only $2-3 \%$ of his total potassium per day, the error introduced by failing to measure fecal and sweat losses in the normal is less than $0.5 \%$ of total body potassium. Consequently, only urinary excretion has been examined in this study but it should be remembered in extension of this method to patients that significant amounts of tracer may at times escape by other routes.

Urinary loss of $\mathrm{K}^{42}$ in the normal subjects studied (Figure 5) was small enough that equilibrium was reached before $5 \%$ of the injected dose had been excreted but variable enough (2.5$7.5 \%$ in the first 40 hours) that individual correction for loss had to be made in each measurement of exchangeable potassium. This variability is largely explained by the fact that $\mathrm{K}^{42}$ excretion 
depended on natural potassium excretion which covered a wide range of concentration and rate (Table VII). After the initial ten hours of greatest variation (because of higher plasma specific activity), the urinary excretion of tracer per 24 hours was about $2.3 \%$ of injected dose and the urinary excretion of natural potassium was about 78 meq./day or $2.3 \%$ of potassium content. Total excretion including feces and sweat was then approximately $85 \mathrm{meq} . /$ day.

\section{CONCLUSIONS}

We may conclude that the amount of potassium which will exchange with administered $\mathrm{K}^{42}$ can be accurately measured using the "equilibrium" specific activity of urine potassium. Use of the modifier "exchangeable" follows from the variations in tissue exchange rates and from the time limitation imposed by safe tracer doses of short-lived $\mathrm{K}^{42}$ which necessitates making measurements before specific activity is uniform throughout the body. The exchangeable potassium content is probably $5 \%$ less than total body potassium, the difference being $30 \%$ of the potassium of red cells, brain and bone which is unexchanged at 40 hours after $\mathrm{K}^{42}$ administration. More precise knowledge of these relationships awaits improvement of present techniques to reduce experimental error below 5\%. Whatever the difference, such exchangeable potassium measurements reveal for the first time the amount of "available," "active," or "freely exchangeable" potassium in the body, which may be found to have greater physiological significance than the total amount present.

\section{SUM MARY}

(1) The principle of isotope dilution is applied to measurement of the quantity of potassium in a living man which will exchange with administered $\mathrm{K}^{\mathbf{4 2}}$. The method utilizes urine specific activity as representative of overall body exchange.

(2) The exchangeable potassium content of 29 healthy young men determined by this method varies from 37.0 to $57.1 \mathrm{meq} . / \mathrm{kg}$. body weight with the mean 46.3 . Reproducibility is within $4 \%$ of the mean. The correlation with surface area, basal oxygen consumption, plasma volume, thio- cyanate space and total body water are not sufficiently better than that with body weight to war- rant their use as a basis for estimating the exchangeable potassium content. A close relationship between exchangeable potassium and 24 hour urine creatinine in five subjects warrants further study.

(3) Potassium exchange in the human is shown to be similar to that of other animals-rapid in most viscera, fairly rapid in muscle but slow enough in red cells, brain and, probably, bone that complete exchange is not accomplished in 40 hours.

(4) Urine specific activity is shown in rabbits to equal mean body specific activity at 40 hours within an experimental error of $5 \%$. Both human and rabbit tissue exhange data indicate that the exchangeable potassium content is probably $5 \%$ less than the actual amount of potassium in the body. Although recently ingested potassium has a disproportionately high representation in urine, the effect on urine specific activity of large oral potassium loads is small.

(5) Total excretion of $\mathrm{K}^{42}$ in normal subjects is closely approximated by urinary excretion which varied in this group from $2.5 \%$ to $7.5 \%$ of dose during the first 40 hours.

(6) Isotope effects, toxicity, and sources of error are discussed.

(7) It is concluded that this method offers the investigator a practical new device for the study of electrolyte changes in the living human.

\section{BIBLIOGRAPHY}

1. Moore, F. D., Determination of total body water and solids with isotopes. Science, 1946, 104, 157.

2. Schloerb, P. R., Friis-Hansen, B. J., Edelman, I. S., Solomon, A. K., and Moore, F. D., The measurement of total body water in the human subject by deuterium oxide dilution. J. Clin. Invest., 1950, 29, 1296.

3. Forbes, G. B., and Perley, A. M., Determination of total body sodium in man with radiosodium". J. Lab. \& Clin. Med., 1949, 34, 1599.

4. Marinelli, L. D., Quinby, E. H., and Hine, G. J., Dosage determination with radioactive isotopes. II. Practical considerations in therapy and protection. Am. J. Roentgenol., 1948, 59, 260.

5. Folin, O., Laboratory Manual of Biological Chemistry with Supplement. D. Appleton-Century Co., Inc., New York, 1934, 5th ed., pp. 241 and 353.

6. Peters, J. P., and Van Slyke, D. D., Quantitative Clinical Chemistry. Vol. I. Interpretations. The Williams \& Wilkins Co., Baltimore, 1946, 2nd ed. $(a)$, p. 29 ; $(b)$, p. 908 . 
7. Crandall, L. A., Jr., and Anderson, M. X., Estimation of the state of hydration of the body by the amount of water available for the solution of sodium thiocyanate. Am. J. Digest. Dis. \& Nutrition, 1934, 1, 126.

8. Gibson, J. G., 2nd, and Evelyn, K. A., Clinical studies of the blood volume. IV. Adaptation of the method to the photoelectric microcolorimeter. J. Clin. Invest., 1938, 17, 153.

9. Peters, J. H., The determination of creatinine and creatine in blood and urine with the photoelectric colorimeter. J. Biol. Chem., 1942, 146, 179.

10. Shohl, A. T., Mineral Metabolism. American Chemical Society Monograph Series. Reinhold Publishing Corp., New York, 1939, pp. 19-20.

11. Hastings, A. B., The electrolytes of tissues and body fluids. The Harvey Lectures, 1940-1941, 36, 91.

12. Rathbun, E. N., and Pace, N., Studies on body composition. I. The determination of total body fat by means of the body specific gravity. J. Biol. Chem., 1945, 158, 667.

13. Pace, N., and Rathbun, E. N., Studies on body composition. III. The body water and chemically combined nitrogen in relation to fat content. J. Biol. Chem., 1945, 158, 685.

14. Pace, N., Kline, L., Schachman, H. K., and Harfenist, M., Studies on body composition. IV. Use of radioactive hydrogen for measurement in vivo of total body water. J. Biol. Chem., 1947, 168, 459.

15. Soberman, R., Brodie, B. B., Levy, B.B., Axelrod, J., Hollander, V., and Steele, J. M., The use of antipyrine for the measurement of total body water in man. J. Biol. Chem., 1949, 179, 31.

16. Schwartz, I. L., Schachter, D., and Freinkel, N., The measurement of extracellular fluid in man by means of a constant infusion technique. J. Clin. Invest., 1949, 28, 1117.

17. Overman, R. R., Permeability alterations in disease. J. Lab. \& Clin. Med., 1946, 31, 1170.

18. Kamen, M. D., Use of isotopes in biochemical re- search ; fundamental aspects. Ann. Rev. Biochem., 1947, 16, 631.

19. Urey, H. C., Oxygen isotopes in nature and in the laboratory. Science, 1948, 108, 489.

20. Fenn, W. O., Bale, W. F., and Mullins, L. J., The radioactivity of potassium from human sources. J. Gen. Physiol., 1942, 25, 345.

21. Lasnitzki, A., and Brewer, A. K., The isotopic constitution of potassium in normal tissue and cancer from human subjects. Cancer Research, 1942, 2, 494.

22. Joseph, M., Cohn, W. E., and Greenberg, D. M., Studies in mineral metabolism with the aid of artificial radioactive isotopes. II. Absorption, distribution and excretion of potassium. J. Biol. Chem., 1939, 128, 673.

23. Hahn, L., and Hevesy, G., Rate of penetration of ions through the capillary wall. Acta physiol. Scandinav., 1941, 1, 347.

24. Noonan, T. R., Fenn, W. O., and Haege, L., The distribution of injected radioactive potassium in rats. Am. J. Physiol., 1941, 132, 474.

25. Fenn, W. O., Noonan, T. R., Mullins, L. J., and Haege, L. F., The exchange of radioactive potassium with body potassium. Am. J. Physiol., 1941, 135, 149.

26. Lowry, O. H., and Hastings, A. B., Histochemical changes associated with aging. I. Methods and calculations. J. Biol. Chem., 1942, 143, 257.

27. Berliner, R. W., and Kennedy, T. J., Jr., Renal tubular secretion of potassium in the normal dog. Proc. Soc. Exper. Biol. \& Med., 1948, 67, 542.

28. Dietrick, J. E., Whedon, G. D., and Shorr, E., Effects of immobilization upon various metabolic and physiological functions of normal men. Am. J. Med., 1948, 4, 3.

29. Keutmann, E. H., Bassett, S. H., and Warren, S. L., Electrolyte balances during artificial fever with special reference to loss through the skin. J. Clin. Invest., 1939, 18, 239. 